PRACE GEOGRAFICZNE

zeszyt 148, 2017, 55-79

doi: $10.4467 / 20833113$ PG.17.003.6271

Instytut Geografii i Gospodarki Przestrzennej UJ

Wydawnictwo Uniwersytetu Jagiellońskiego

\title{
WYPEYWY WÓD PODZIEMNYCH W DNACH MIS JEZIORNYCH NA PRZYKŁADZIE JEZIORA RADUŃSKIEGO GÓRNEGO (POJEZIERZE KASZUBSKIE)
}

\author{
Roman Cieśliński, Jacek Piekar:
}

\section{Outflows of groundwater at the bottoms of lake basins on the example of Lake Raduńskie Górne (Kashubian Lake District)}

\begin{abstract}
The aim of the study was to locate and describe groundwater outflows in a selected lake basin. The second aim was to measure spring discharge and measure physical characteristics of the studied waters (temperature, conductivity). The time scope of the work comprised the period from January 2011 to September 2012. The spatial scope of the work included the area of Lake Raduńskie Górne located in the Kashubian Lake District in northern Poland. The study consisted mostly of fieldwork and reviewing archived materials. Four groundwater outflows were located in the course of the study. Their total discharge was $4.61 \cdot \mathrm{s}^{-1}$ and ranged between 0.5 and $2.51 \cdot \mathrm{s}^{-1}$. This produces an annual yield of about $145,000 \mathrm{~m}^{3} \cdot \mathrm{yr}^{-1}$. This value is comparable to that for other lakes in the world. In effect, Lake Raduńskie Górne receives about $0.15 \%$ of its water from under-lake springs. This is a minute value in comparison with the lake's total groundwater recharge $\left(97 \mathrm{mln} \mathrm{m}^{3}\right.$ per year). However, it must be assumed that the actual number of under-lake springs is many times greater than that identified in the course of this study, which means that the share of water supplied in this manner is likely much higher and its effect on water chemistry and water levels in the lake is also likely much more pronounced.
\end{abstract}

Keywords: groundwater outflows, lake, water balance, basin, drowned source 
Zarys treści: Celem głównym opracowania było odnalezienie i opisanie wypływów wód podziemnych w misie wybranego jeziora. Prace miały charakter pilotażowy; obejmowały tylko małą część analizowanej misy jeziornej. Celem dodatkowym było zmierzenie wydajności źródeł zlokalizowanych na dnie misy jeziornej oraz określenie właściwości fizycznych analizowanej wody (temperatura, przewodność właściwa). Zakres czasowy badań objął okres od stycznia 2011 r. do września 2012 r., a przestrzenny - obszar Jeziora Raduńskiego Górnego zlokalizowanego na Pojezierzu Kaszubskim. Metody obejmowały prace terenowe oraz przegląd materiałów archiwalnych. W trakcie badań terenowych odnaleziono w misie Jeziora Raduńskiego Górnego cztery wypływy wód podziemnych. Ich łączna wydajność wyniosła $4,6 \mathrm{dm}^{3} \cdot \mathrm{s}^{-1}$ i wahała się od $0,5 \mathrm{do} 2,5 \mathrm{dm}^{3} \cdot \mathrm{s}^{-1} \mathrm{w}$ zależności od punktu pomiarowego. Dodatkowo odnaleziono 15 wypływów wokół misy jeziora, których wydajność wyniosła $13,8 \mathrm{dm}^{3} \cdot \mathrm{s}^{-1}$. W przypadku wypływów podjeziornych - gdyby ich wydajność była stała, dałoby to w skali roku dopływ na poziomie około $145000 \mathrm{~m}^{3}$, czyli Jezioro Raduńskie Górne otrzymywałoby ok. $0,15 \%$ dopływu z tego źródła zasilania. Jednakże dopływ ten jest prawdopodobnie zmienny sezonowo, przez co należy przyjąć, że w skali roku daje wartość na poziomie około $75000 \mathrm{~m}^{3}$, co odpowiada udziałowi rzędu 0,08\%. Należy założyć, że ze względu na przebadanie tylko ok. 0,5\% powierzchni jeziora rzeczywista liczba takich źródeł jest wielokrotnie większa niż określona w trakcie badania. Potwierdzeniem tego faktu mogą być obliczenia bilansu wodnego wykonane dla jeziora, gdzie szacuje się, że dopływ do Jeziora Raduńskiego Górnego drogą podziemną wynosi $97 \mathrm{mln} \mathrm{m}^{3}$ rocznie. W przypadku zsumowania wydajności wypływów podjeziornych i tych zlokalizowanych wokół misy jeziora otrzymamy z kolei wynik na poziomie $18,4 \mathrm{dm}^{3} \cdot \mathrm{s}^{-1}, \mathrm{co}$ w skali roku daje wartość około $580263 \mathrm{~m}^{3}$. Oczywiście i w tym przypadku jest ona zawyżona, gdyż część z wypływów pojawia się sezonowo, a wydajność jest zmienna w czasie.

Stowa kluczowe: wypływy wód podziemnych, jezioro, bilans wodny, zlewnia, źródło podjeziorne

\section{Wprowadzenie}

Jeziora stanowią niezwykle cenne i istotne elementy w przestrzeni geograficznej, które decydują o obiegu wody w zlewni, będąc naturalnymi zbiornikami retencyjnymi. Są one obiektami, które jednocześnie mogą mieć charakter drenujący i alimentujący. Niestety przy obliczeniu bilansu wodnego danego jeziora napotkać można wiele problemów wynikających z braku informacji na temat zasilania drogą podziemną. Wynika to z niewielkiej ilości danych hydrogeologicznych dla obszarów, na których są one zlokalizowane. W związku z tym najczęściej stosowaną metodą do oceny wielkości zasilania jezior drogą podziemną są obliczenia wynikające z różnicy bilansowej (Gutry-Korycka, Bajkiewicz-Grabowska 1981). Bardzo często stosuje się założenie, że dopływ i odpływ wód podziemnych bilansuje się. Obecnie coraz częściej stosuje się metodę modelowania matematycznego (Mioduszewski i in. 2004; Jaworska-Szulc 2015) i metodę źródeł reprezentatywnych (Tarka 1995). Wykonywane są także pomiary rzeczywiste wydajności źródeł, które dowiązuje się do danych przepływu mierzonych na profilu zamykającym zlewnię i danych opadowych (Tomalski, Tomaszewski, 2007). 
Jedną z dróg zasilania jezior jest dopływ ze źródeł zlokalizowanych bezpośrednio przy misie jeziornej (niektóre z nich przy wysokich stanach wody mogą być zanurzone). Drugą formą zasilania podziemnego może być zasilanie z dna mis jeziornych (wychodnie warstw wodonośnych, źródła) (Shanks, Callender 1992). Na temat liczby i wydajności wypływów wód podziemnych, w tym źródeł, na dnie jezior istnieje niewiele pozycji literatury. Do najważniejszych z nich zaliczyć należy prace Harveya i in. (2000), w której autorzy oszacowali objętość przepływu wód w dużych jeziorach, Choińskiego i in. (2008), gdzie na przykładzie jezior w Polsce omówiono wielkość zasilania jezior za pośrednictwem źródeł położonych na ich dnie. Ponadto Choiński i Ptak (2012) omawiają różnice w grubości pokrywy lodowej na jeziorze Samołęskie wynikające z dostaw wód podziemnych. Yihdego i Becht (2013) dyskutują za pomocą modelu DEM oraz trójwymiarowego modelu przepływu wpływ zasilania podziemnego na wody jeziora Naivasha w Kenii. Najczęściej jednak w literaturze znaleźć można opis dróg wymiany pomiędzy wodą jeziorną a wodą podziemną w strefie litoralu (Schuster i in. 2003; Kidmose 2010), zagadnienia hydrochemiczne kontaktu wód podziemnych z powierzchniowymi (Dash i in. 2008), w tym teoretyczną wymianę nutrientów pomiędzy wodami jeziornymi i podziemnymi (Li, Wang 2007), modelowanie mechanizmów zanieczyszczeń (Arfib i in. 2002), a także procesy i efekty wymiany makro- i mikroskładników pomiędzy osadami jeziornymi a wodą naddenną w jeziorze (Engstrom, Swain 1986; Rainey i in. 2000; Kaleris 2006).

Na temat zasilania jezior poprzez wypływy wód podziemnych pisał także Meyboom (1967), który prowadził badania dla obszarów młodoglacjalnych zachodniej Kanady. Powiązał on wielkość tego zasilania ze zmianami warunków hydrologicznych w określonych porach roku. Z kolei Krabbenhoft i in. (1990) dokonali obliczeń zasilania jezior drogą podziemną za pomocą bilansu masy izotopu, a następnie wykonania modelu hydrologicznego. Również Hunt i in. (2004) do obliczeń zasilania jezior drogą podziemną wykorzystał model matematyczny, z tym że zasilanie to rozpatrywane było w różnych skalach. W części prac podjęta została tematyka związaną z zasilaniem jezior przez źródła znajdujące się na dnie zbiornika. Pisali o tym m.in.: Shaw i Prepas (1990), Bohacs i in. (2000) czy Wüest i Lorke (2003). W przypadku badań dotyczących bezpośrednio Jeziora Raduńskiego Górnego i wód podziemnych na obszarze Pojezierza Kaszubskiego należy wymienić następujące opracowania: Jankowska 1979, 1984; Okulanis 1981; Drwal 1982; Lange 2005; Jaworska-Szulc 2015; Jaworska-Szulc i in. 2015.

Wypływy wód podziemnych na powierzchnię terenu stanowią istotny element krążenia wody w przyrodzie. Pełnią funkcję łącznika między wodami podziemnymi i powierzchniowymi (Jokiel 2007). Ich występowanie jest ściśle skorelowane z określonymi warunkami budowy geologicznej, rzeźby terenu i warunkami klimatycznymi. Sprzyjające występowaniu licznych wypływów są: zróżnicowana rzeźba 
terenu, naprzemianległe ułożenie warstw przepuszczalnych i słabo przepuszczalnych, a także wysokie zasilanie atmosferyczne.

Źródłem jest miejsce, w którym w sposób naturalny, samoczynny, skoncentrowany bądź nieskoncentrowany następuje wypływ wody podziemnej na powierzchnię terenu (Tomaszewski 1989; Moniewski 2007). Ważnym typem źródeł bezpośrednio związanym z tematem artykułu jest źródło zatopione. W tym przypadku miejsce wypływu znajduje się poniżej zwierciadła wód powierzchniowych (Younger 2009). Ilościowo przeważają wypływy zlokalizowane w dnie koryta rzecznego, które nacinają warstwę wodonośną lub odkrywają prowadzącą do niej szczelinę (Taniguchi i in. 2002). Kolejnym z rodzajów źródeł podwodnych jest źródło basenowe. Znajduje się ono w dnie niewielkiego zbiornika utworzonego w miejscu utrudnionego odpływu wody (Fetter 2010). Najważniejszym typem ze względu na tematykę pracy jest źródło podjeziorne. Występuje ono w dnach jezior, których misa rozcina warstwę wodonośną (Moniewski 2007).

Celem opracowania było zlokalizowanie oraz opis wypływów wód podziemnych w wybranej misie jeziornej. Założono, że jeziora Pojezierza Kaszubskiego charakteryzują się taką formą zasilania. Celem dodatkowym badań było oszacowanie wydajności znalezionych wypływów oraz ustalenie różnic właściwości fizycznych wód wypływów i wód jeziornych.

Prace terenowe były prowadzone w okresie od stycznia 2011 r. do września 2012 r. Poligon badawczy objął NE fragment Jeziora Raduńskiego Górnego, leżącego w Polsce północnej, na Pojezierzu Kaszubskim (ryc. 1). Powierzchnia poligonu badawczego wyniosła około 0,5\% powierzchni całkowitej jeziora. Prace miały zatem charakter pilotażowy, gdyż obejmowały małą część analizowanej misy jeziornej.

\section{Metody i materiały źródłowe}

Na podstawie materiałów źródłowych oraz informacji uzyskanych z różnych instytucji państwowych do badań wytypowano rynnowe Jezioro Raduńskie Górne. Materiałami źródłowymi były m.in.: Szczegółowa mapa geologiczna Polski w skali 1: 50 000, arkusz Stężyca wraz z objaśnieniami; Mapa hydrogeologiczna Polski w skali 1: 50 000, arkusz Stężyca, Mapa głębokości występowania głównego poziomu wodonośnego w skali 1: 50 000, arkusz Stężyca; Mapa miąższości i przewodności głównego poziomu wodonośnego w skali 1: 50 000, arkusz Stężyca; Syntetyczny profil geologiczny część wschodnia obszaru z rynną Jeziora Raduńskiego Górnego do SMGP w skali 1: 50 000, arkusz N-33-72-B Stężyca; Mapa hydrograficzna Polski w skali 1: 50 000, arkusz N-33-72-B Stężyca. W pracy wykorzystano również pozycje literatury m.in. takich autorów, jak Okulanis (1981), Jankowska (1984) czy Borowiak i Barańczuk (2005), którzy badali szczegółowo Jezioro Raduńskie Górne. Istotne okazały się także wypowiedzi ustne dra Janusza Dworniczaka z Katedry Geomorfologii i Geologii Czwarto- 


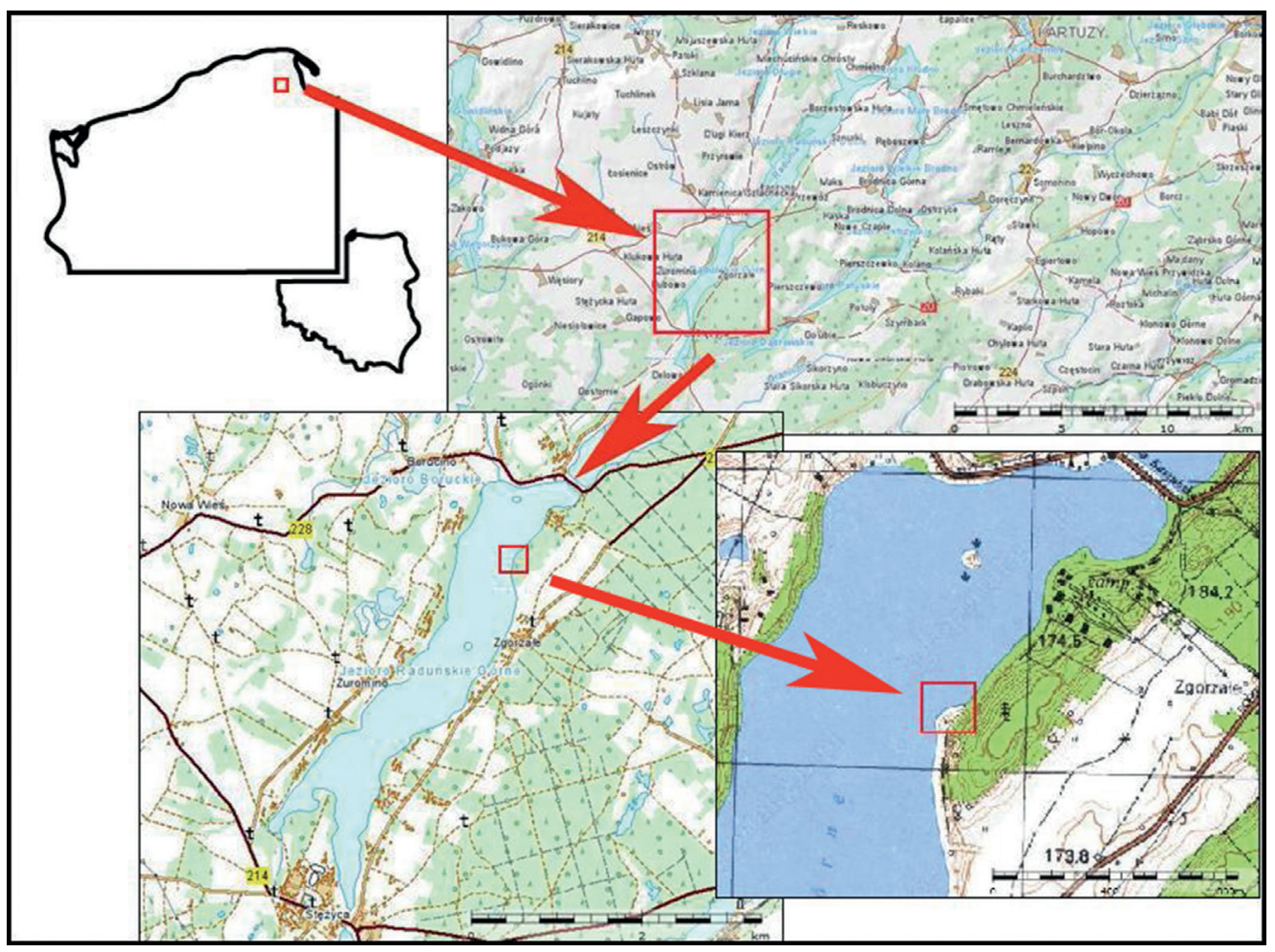

Ryc. 1. Jezioro Raduńskie Górne wraz z poligonem badawczym

Fig. 1. Lake Raduńskie Górne with the research area

rzędu Uniwersytetu Gdańskiego, dr Katarzyny Bociąg z Katedry Ekologii Roślin Uniwersytetu Gdańskiego, komandora Zygfryda Naczka ze Stowarzyszenia Oficerów Rezerwy 34. Pułku Lotnictwa Myśliwskiego i Sympatyków Lotnictwa, oraz mgra inż. Leszka Jurysa z Państwowego Instytutu Geologicznego. Wypowiedzi te wskazywały bezpośrednio lub pośrednio, gdzie mogą być zlokalizowane wypływy wód podziemnych w Jeziorze Raduńskim Górnym. Wybór tego obiektu uzasadniało duże zróżnicowanie morfologiczne, z naprzemianległym ułożeniem utworów przepuszczalnych i nieprzepuszczalnych, a także nieciągłość warstw wodonośnych oraz ich zróżnicowana miąższość, o czym świadczy przekrój hydrogeologiczny (ryc. 2). Warunkiem sprzyjającym występowaniu wypływów wód podziemnych była obecność wód podziemnych o zwierciadle napiętym. Co ważne, Katedra Geomorfologii i Geologii Czwartorzędu Uniwersytetu Gdańskiego prowadziła w tym jeziorze badania sejsmoakustyczne. Z Katedry Geomorfologii i Geologii Czwartorzędu uzyskano wydruk wykresu z sondy 


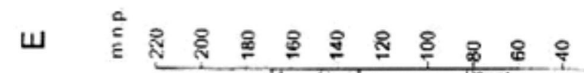

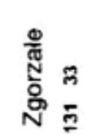

I:

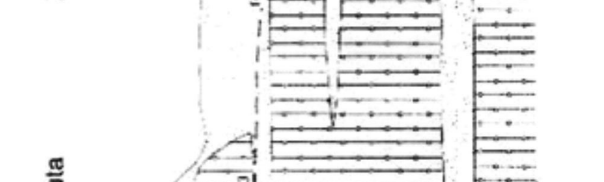

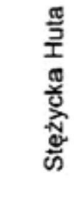
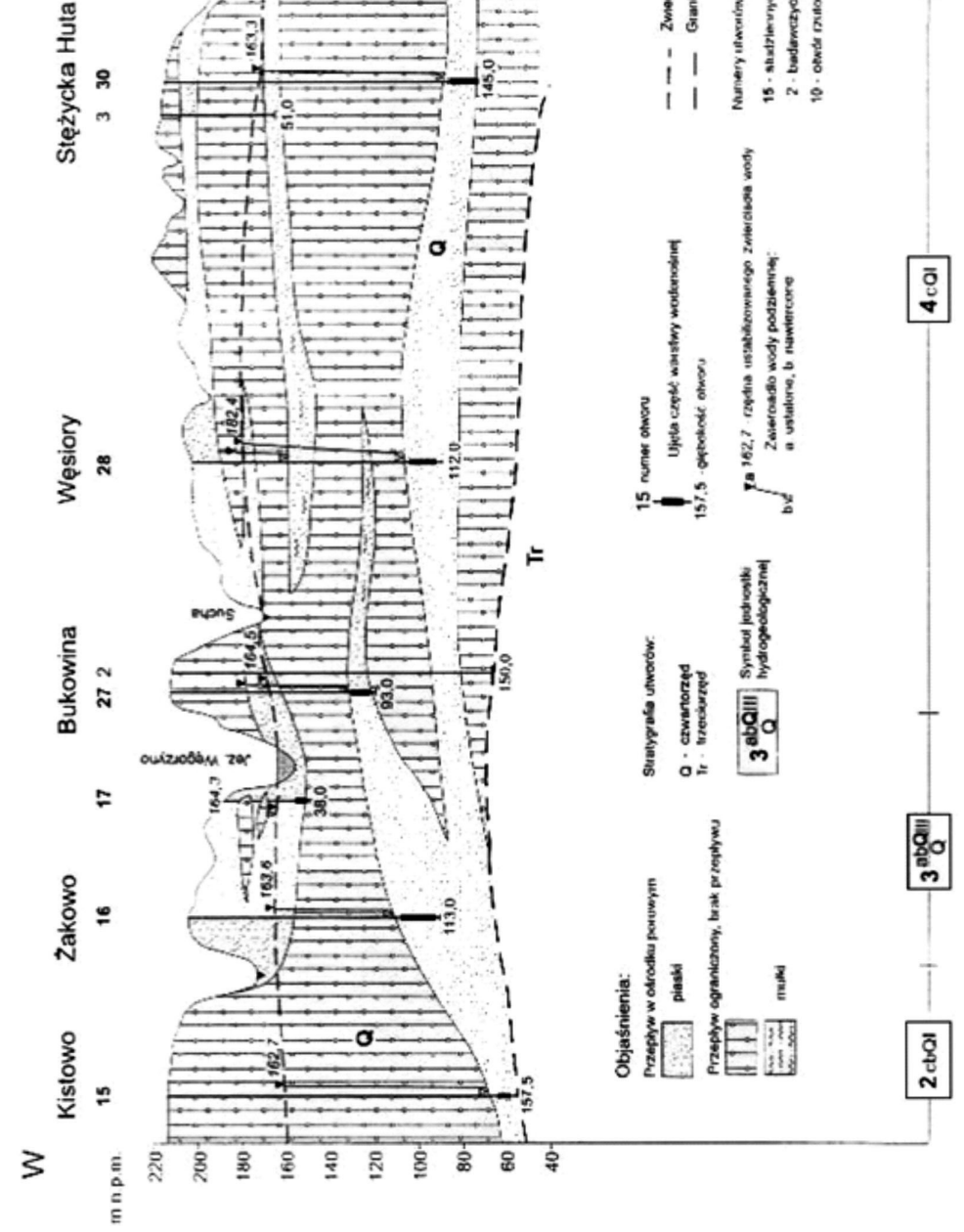

䙜

圆

ఠ̊ㅇㅇ ํํㅇ in 芯 尔 怘 ज. $\dot{8} \frac{\mathscr{E}}{\infty}$ ㄴ. $\ddot{-}=$ $\frac{\pi}{n} \ddot{1}$ $3 \frac{0}{8}$ 酷空 至 可 츨 07 응 so 응 츨 类 옼ㅁ $\sum \frac{1}{9}$ 응 公。 응 음 응 导 $\infty$ 은 등 인 논 至 i 这 
sejsmoakustycznej. Był to wykres przedstawiający punkt w centralnej części jeziora, gdzie zauważono zaburzenie w dnie zbiornika (ryc. 3). Uznano, że warstwa osadów na dnie była nieciągła i że może to być miejsce potencjalnego wypływu. Miejsce to znajduje się na stoku, na głębokości ok. $37 \mathrm{~m}$.
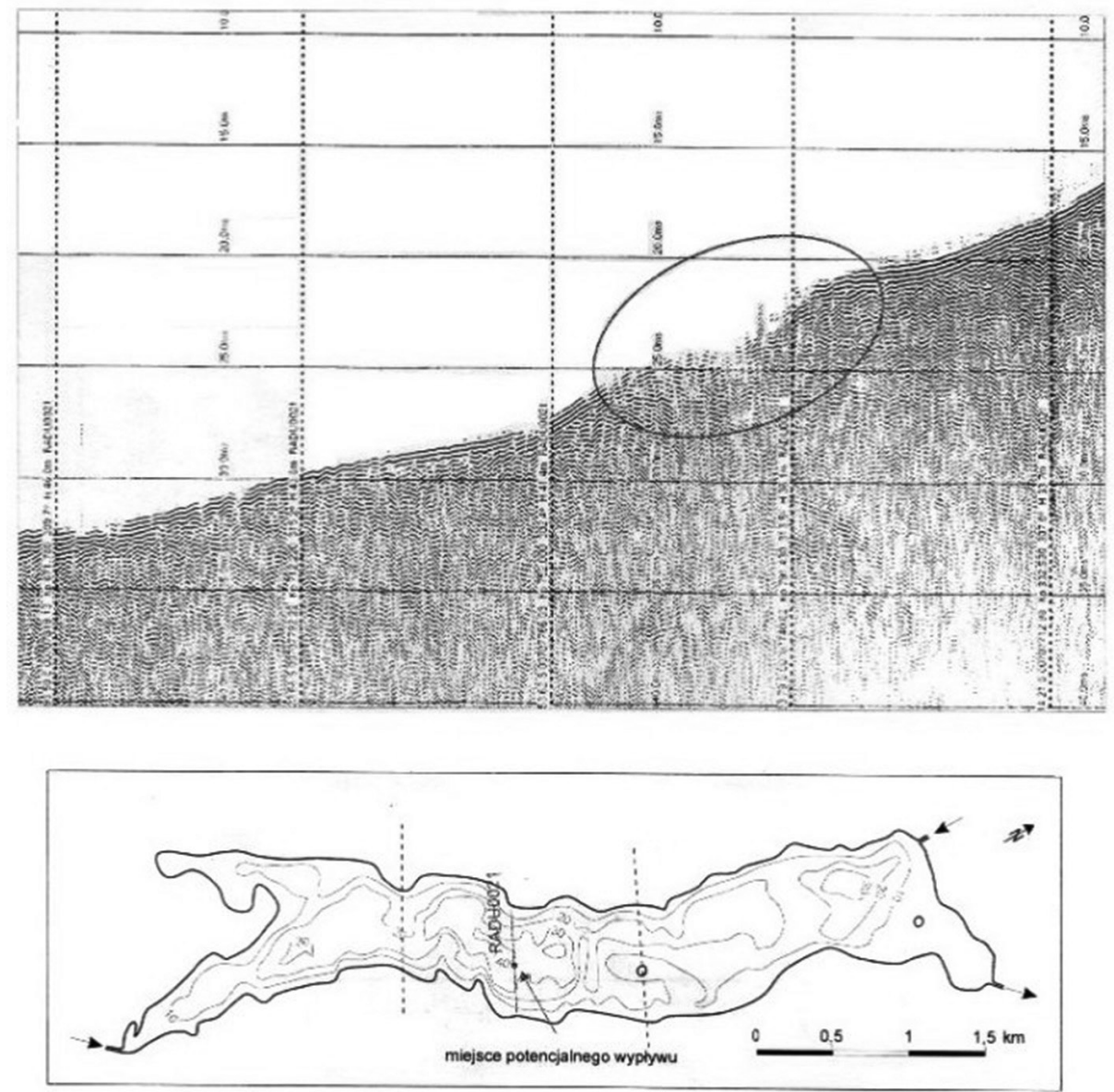

Ryc. 3. Wydruk z sondy sejsmoakustycznej na jeziorze Raduńskim Górnym uzyskany z Katedry Geomorfologii i Geologii Czwartorzędu Uniwersytetu Gdańskiego (prostokątem zaznaczono miejsce badań)

Fig. 3. Print-out from the seismoacoustic probe on Lake Raduńskie Górne obtained from the Department of Geomorphology and Quaternary Geology at the University of Gdańsk (rectangle indicates the research area) 
Dalsze badania wytypowanego do analiz jeziora prowadzono już w terenie. Na wstępie wybrano poligon badawczy (ryc. 1).

Celem prac terenowych było znalezienie wypływów wód podziemnych w Jeziorze Raduńskim Górnym przy wykorzystaniu techniki nurkowania. Podczas zanurzenia była prowadzona dokumentacja audiowizualna przy użyciu aparatu Nikon D90 z obudową podwodną Ikelite Nikon D90 oraz lampą Ikelite DS 161 movie oraz kamerą GoPro HD HERO 2 Outdoor.

Pierwsze nurkowanie wykonano w dniach 28-29 stycznia 2012 r. Kolejne odbyły się 23 marca 2012 r., 18 kwietnia 2012 r. oraz 6 września 2012 r.

Dnia 18 kwietnia 2012 r. odbył się drugi wyjazd na poligon badawczy. Podczas tego wyjazdu wykonano pomiary do stworzenia szczegółowego planu batymetrycznego obszaru badań. Do tego celu użyto Echosondę FISHFINDER 300 C oraz GPS ETREX LEGEND firmy Garmin. Na ich podstawie opracowano szczegółowy plan batymetryczny poligonu badawczego.

Aby określić, czy mamy do czynienia z wypływami wód podziemnych na dnie misy jeziora, wykonano - przy użyciu miernika wieloparametrowego 350 firmy WTW pomiary temperatury i przewodności właściwej wód. Pomiary te zrealizowano zimą i latem. Technika pomiarowa polegała na nałożeniu rury PCV na źródło, następnie odpompowaniu znajdującej się w rurze wody (stanowiącej jeszcze wodę jeziorną) i właściwym pomiarze. Dodatkowo oszacowano wydajności źródeł. Podobnie jak w przypadku określenia właściwości fizycznych pomiar wydajności zrobiono poprzez nałożenie przezroczystej i wyskalowanej rury PGV na źródło i zmierzenie w określonym czasie ilości wody wypływającej.

W pracy wykorzystano także badania terenowe przeprowadzone w latach 2010_ 2011. W ich trakcie dokonano inwentaryzacji wypływów wód podziemnych w zlewni Jeziora Raduńskiego Górnego oraz określono - przy użyciu metody wolumetrycznej i młynka elektromagnetycznego Valleport - ich wydajności.

Metody kameralne miały na celu zgromadzenie danych, a następnie zapoznanie się z materiałami źródłowymi oraz kartograficznymi, o których wspomniano wcześniej. Do opracowania materiałów kartograficznych użyto programu MapInfo Professional 9.5, wykonując mapy obrazujące treści pracy.

\section{Wody powierzchniowe}

Jezioro Raduńskie Górne należy do zespołu jezior raduńsko-ostrzyckich, których łączna powierzchnia wodna wynosi 2165 ha. Jeziora raduńsko-ostrzyckie pod względem hydrograficznym zlokalizowane są w górnym dorzeczu Raduni (ryc. 4). Z jednej strony odgrywają rolę głównego źródła zasilania Raduni, a z drugiej - tworzą naturalny zespół 15 zbiorników retencyjnych o łącznej długości 48,1km (Okulanis 


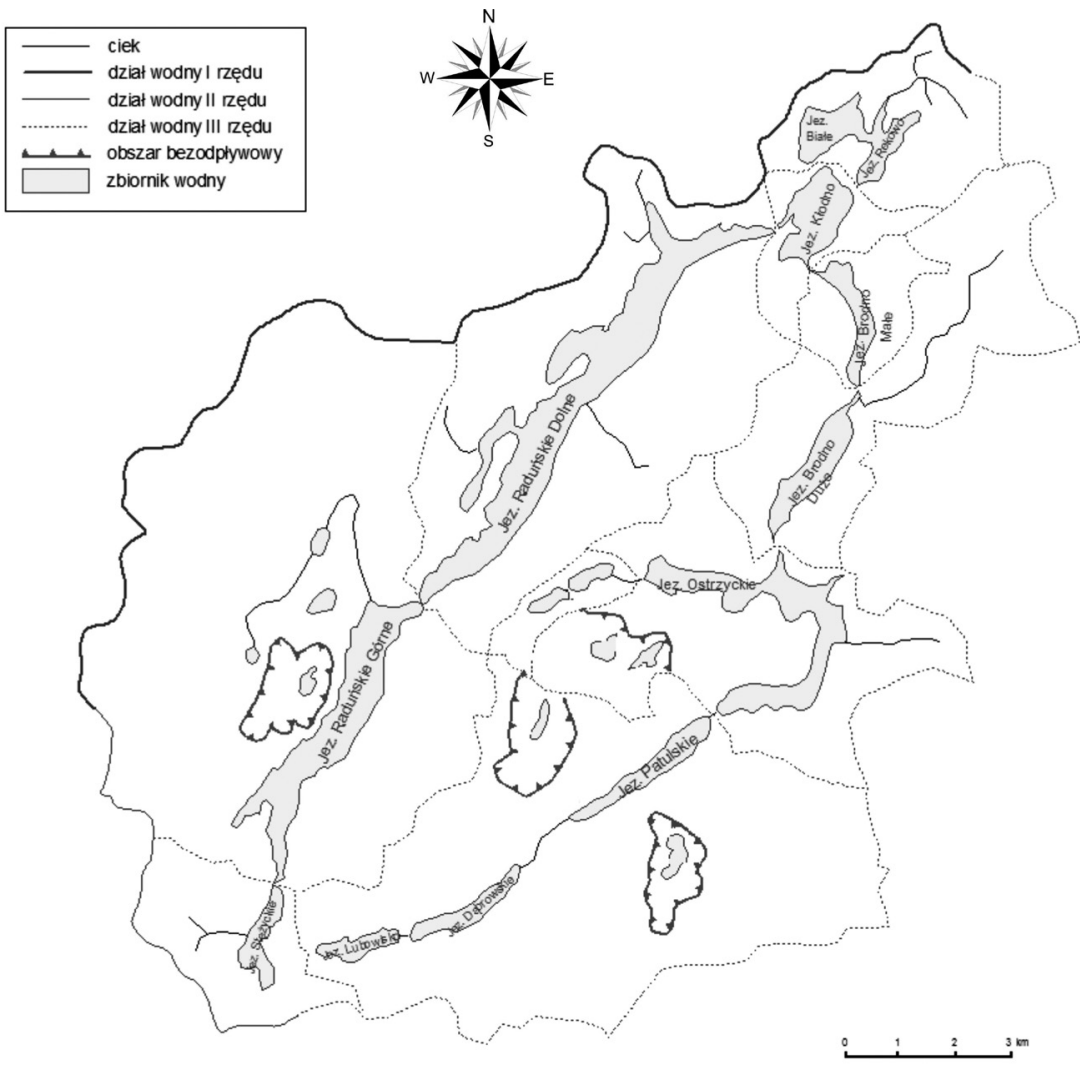

Ryc. 4. Zlewnia Jeziora Raduńskiego Górnego na tle zlewni górnej Raduni (Okulanis 1981 - zmienione)

Fig. 4. Catchment area of Lake Raduńskie Górne against the background of the catchment area of the upper Radunia (Okulanis 1981 - modified)

1981). Ciąg tych akwenów powiązany jest krótkimi połączeniami międzyjeziornymi (przesmykami).

Powierzchnia zwierciadła wody Jeziora Raduńskiego Górnego wynosi 380,5 ha, z czego 0,7 ha stanowią dwie wyspy, jedna położona w centralnej, druga w północnej części zbiornika. Wskaźnik rozwinięcia linii brzegowej wynosi 2,44 (Choiński 2006).

Dno jeziora posiada wiele przegłębień i wypłyceń, przez co jest bardzo urozmaicone. Maksymalna głębokość wynosi 43 m, i znajduje się w środkowej części zbiornika. Analizowane jezioro jest najgłębszym zbiornikiem w zlewni górnej Raduni (dotyczy to też głębokości średniej wynoszącej 15,5 m) (ryc. 5). 


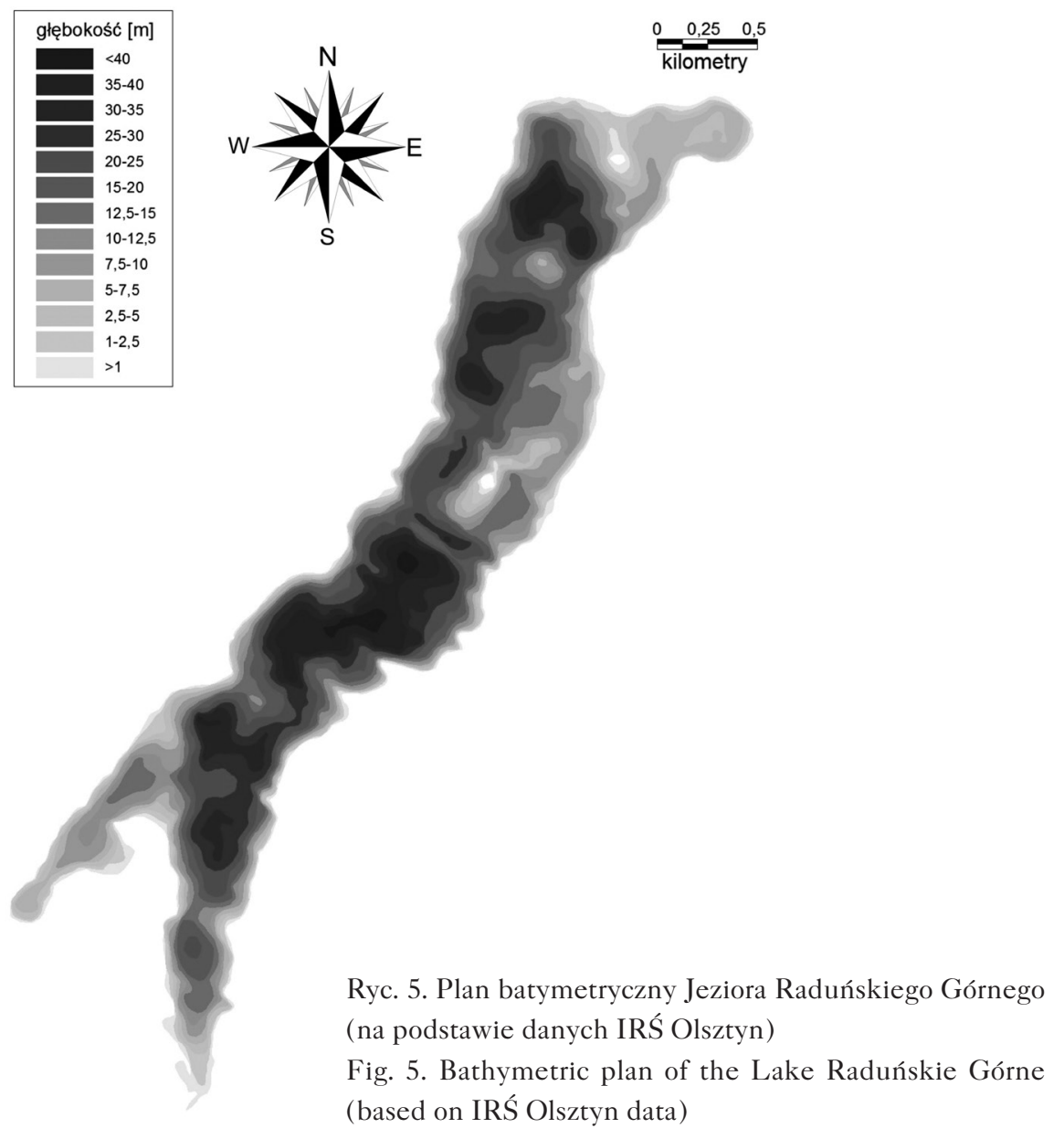

\section{Wody podziemne}

Wody podziemne na omawianym obszarze najpłycej zalegają w dolinach rzecznych oraz w bliskim sąsiedztwie zbiorników wodnych. Na ogół głębokość do zwierciadła wód podziemnych nie przekracza $1 \mathrm{~m}$. Płytkie wody podziemne występują także na powierzchni terenu na obszarze podmokłych zagłębień bezodpływowych (Jereczek-Korzeniewska 2006).

Na obszarze badań zostało stwierdzone występowanie jedynie sandrowego piętra wodonośnego zasilanego przez infiltrację (Lidzbarski 2000). Piętro to jest drenowane 
przez zbiorniki i niewielkie cieki. Strop poziomu sandrowego zalega na głębokości od $10 \mathrm{~m}$ do $25 \mathrm{~m}$. W obniżeniach terenu głębokość ta jest mniejsza niż $5 \mathrm{~m}$. Średnia wartość współczynnika filtracji to $43,2 \mathrm{~m} \cdot 24 \mathrm{~h}^{-1}$. Zwierciadło swobodne pochylone jest w kierunku południowym. Stabilizuje się ono na rzędnej około 160 m n.p.m. (Lidzbarski 2000).

Pierwszy międzymorenowy poziom wodonośny w otoczeniu jezior jest słabo izolowany, przez co jest drenowany. Na obszarze rynien głębokość zalegania poziomu wodonośnego nie przekracza $10 \mathrm{~m}-15 \mathrm{~m}$, a w części wysoczyznowej wynosi $50 \mathrm{~m}$. Poziom ten cechuje wysoki współczynnik infiltracji wynoszący od 20 do $40 \mathrm{~m} \cdot 24 \mathrm{~h}^{-1}$, maksymalnie $84 \mathrm{~m} \cdot 24 \mathrm{~h}^{-1}$. Z kolei głębokość zalegania II poziomu międzymorenowego uzależniona jest od rzędnych powierzchni terenu. W rejonie szczytów wysoczyzny morenowej przekracza $100 \mathrm{~m}$, a na pozostałym obszarze w przedziale: $50 \mathrm{~m}-100 \mathrm{~m}$ (ryc. 6). Współczynnik filtracji mieści się w granicach $5 \mathrm{~m}-25 \mathrm{~m} \cdot 24 \mathrm{~h}^{-1}$, a grubość warstwy wodonośnej w zakresie $15 \mathrm{~m}-40 \mathrm{~m}$ (ryc. 7).

Analiza warunków hydrogeologicznych dowodzi, że między poziomem sandrowym i poziomami międzymorenowymi dochodzi do lokalnego przepływu wód podziemnych, przykładem czego może być zlewnia rzeki Wdy (Szumińska 2014). Prawie cały analizowany obszar stanowi rejon zasilania także dla wód regionalnego krążenia, na co wskazuje przekrój hydrogeologiczny (ryc. 2).

W rejonie dorzecza górnej Raduni drenażowi podlegają wszystkie wymienione poziomy wodonośne (Lidzbarski 2000). Jeziora rynnowe odgrywają główne znaczenie w drenażu wód podziemnych (Borowiak 2006; Błaszkiewicz 2007; Graf 2008). Wpływają one również na formowanie się biegu przepływu wód podziemnych (Jankowska 1984). Rozpowszechnionym oraz charakterystycznym elementem krajobrazu Pojezierza Kaszubskiego są naturalne wypływy wód podziemnych (Drwal 1979). W rejonie obszaru badań powszechnie występującą formą terenu są strome zbocza rynien poglacjalnych (dochodzące do $60^{\circ}$ nachylenia) będące idealnymi warunkami do pojawiania się tych wypływów (Borowiak 2005). Najczęściej występują one w postaci wysięków. Mogą także występować w postaci źródeł punktowych (Drwal 1979). Wydajność tych wypływów dochodzi do $5 \mathrm{l} \cdot \mathrm{s}^{-1}$. Drenują one główne poziomy wodonośne (Borowiak 2005).

\section{Uzyskane wyniki}

Podczas nurkowania w dniu 29 stycznia 2012 r. na głębokości ok. 6 m, w miejscu o współrzędnych geograficznych: 54 14' 45.9” N, 17 59'06.6” E znaleziono wypływ wód podziemnych (ryc. 8).

Dno pod źródłem było piaszczyste, piaszczysto-żwirowe z rozproszonymi grupami różnego rodzaju muszli. Piasek tworzący dno jeziora był ciemny. Bezpośrednie 


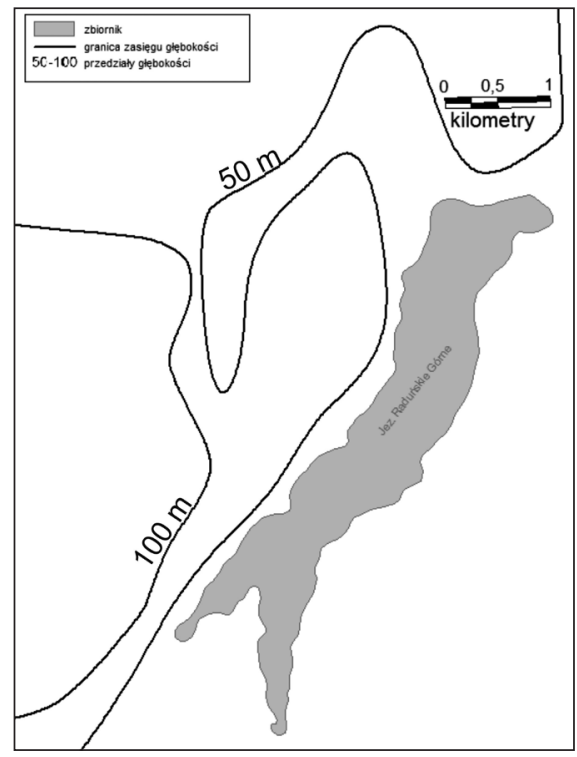

Ryc. 6. Głębokość występowania głównego poziomu wodonośnego, fragment Mapy głębokości występowania głównego poziomu wodonośnego w skali 1:50000, arkusz Stężyca (52) (czarnym kwadratem oznaczono poligon badawczy)

Fig. 6. Depth of occurrence of the main aquifer, Polish Hydrogeological Map in scale 1:50000, sheet Stężyca (52) (black square indicates the research polygon)

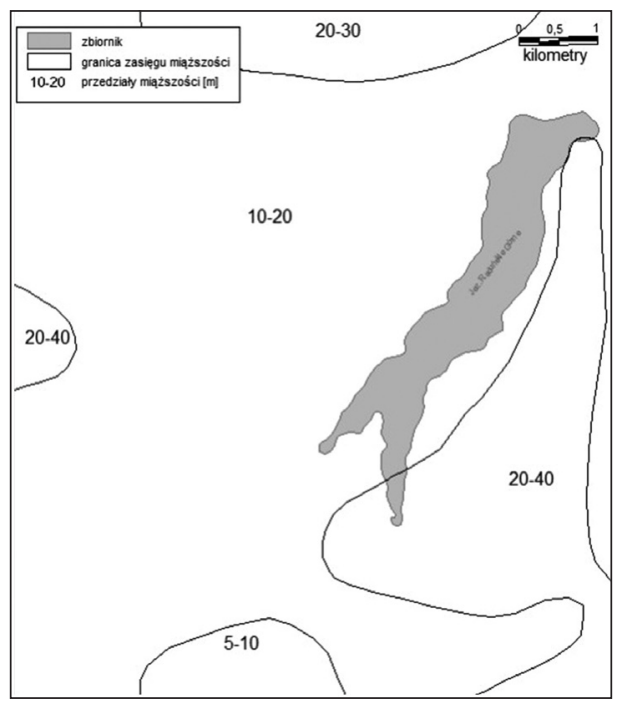

Ryc. 7. Miąższość głównego poziomu wodonośnego, fragment Mapy miąższości i przewodności głównego poziomu wodonośnego w skali 1:50000, arkusz Stężyca (52) (czarnym kwadratem oznaczono poligon badawczy)

Fig. 7. Thickness of the main aquifer, Polish Hydrogeological Map in scale 1:50000, sheet Stężyca (52) (black square indicates the research polygon)

sąsiedztwo wypływu na dnie jeziora charakteryzowało się „białymi łatami” świeżego piasku (ryc. 9). Zauważono kilka takich punktów o jaśniejszej barwie piasku (ryc. 10, 11). Mogły to być miejsca wypływów wód podziemnych.

Miejsce wypływu to charakterystyczny stożek z jasnego piasku (ryc. 8), pośrodku którego znajduje się zagłębienie. Przybliżone wymiary stożka: długość 70 cm, szerokość 25 cm, wysokość $7 \mathrm{~cm}$, długość kopuły stożka $25 \mathrm{~cm}$, długość, na której rozsypany jest piasek, $45 \mathrm{~cm}$, oraz średnica otworu, z którego wypływa woda podziemna, $8 \mathrm{~cm}$.

Wykonany na podstawie pomiarów z dnia 18 kwietnia 2012 r. plan batymetryczny obszaru badań charakteryzuje się gęstą siecią izobat. Świadczy to o stromych stokach podwodnych (ryc. 12). 


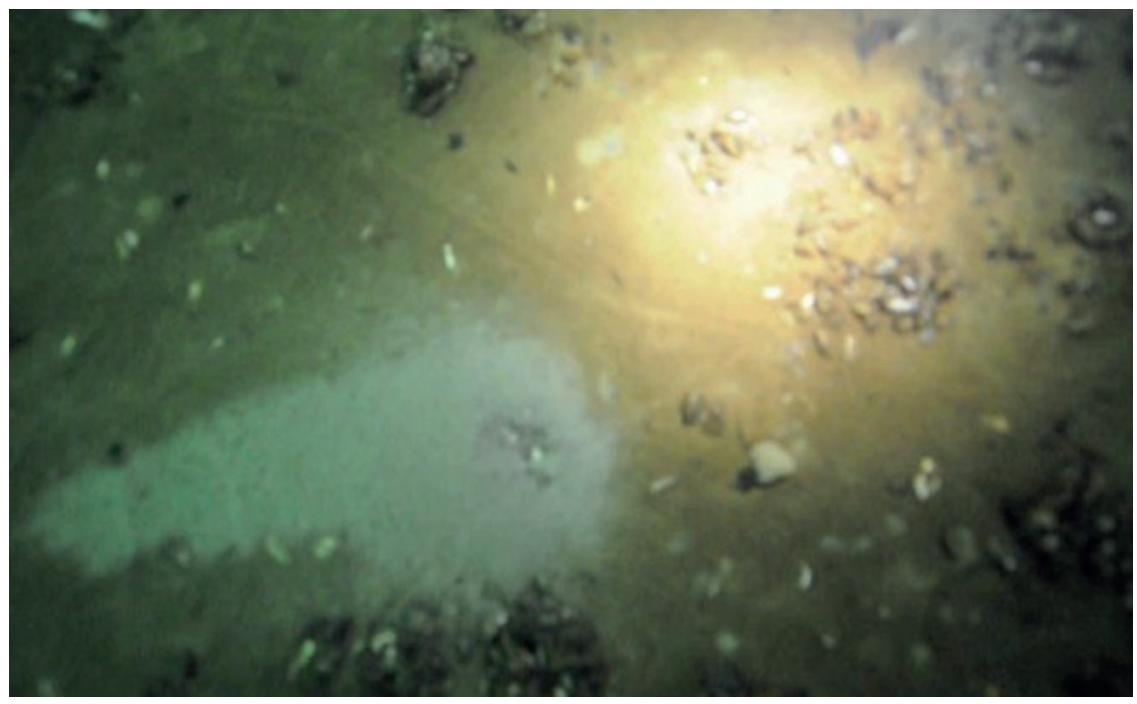

Ryc. 8. Znaleziony wypływ wody podziemnej (nr I) w dnie Jeziora Raduńskiego Górnego (29.01.2012)

Fig. 8. Groundwater outflow (No. I) at the bottom of Lake Raduńskie Górne (29.01.2012)

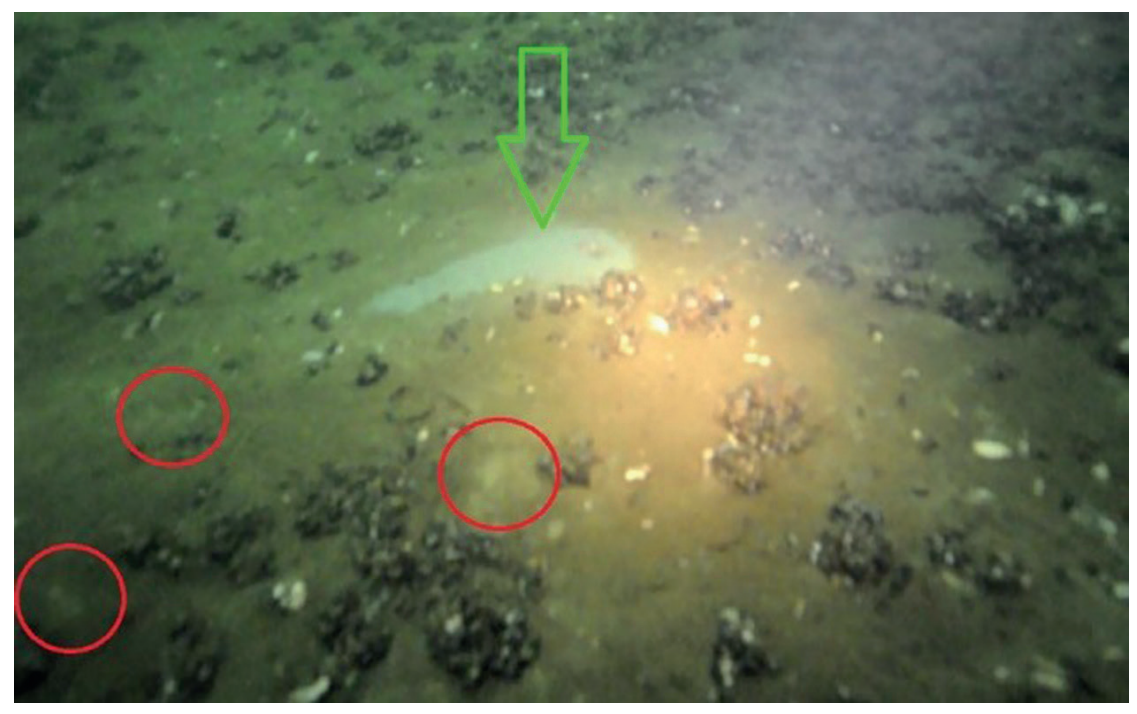

Ryc. 9. „Białe łaty” w pobliżu odnalezionego wypływu nr I (29.01.2012)

Fig. 9. White patches around the groundwater outflow No. I (29.01.2012) 


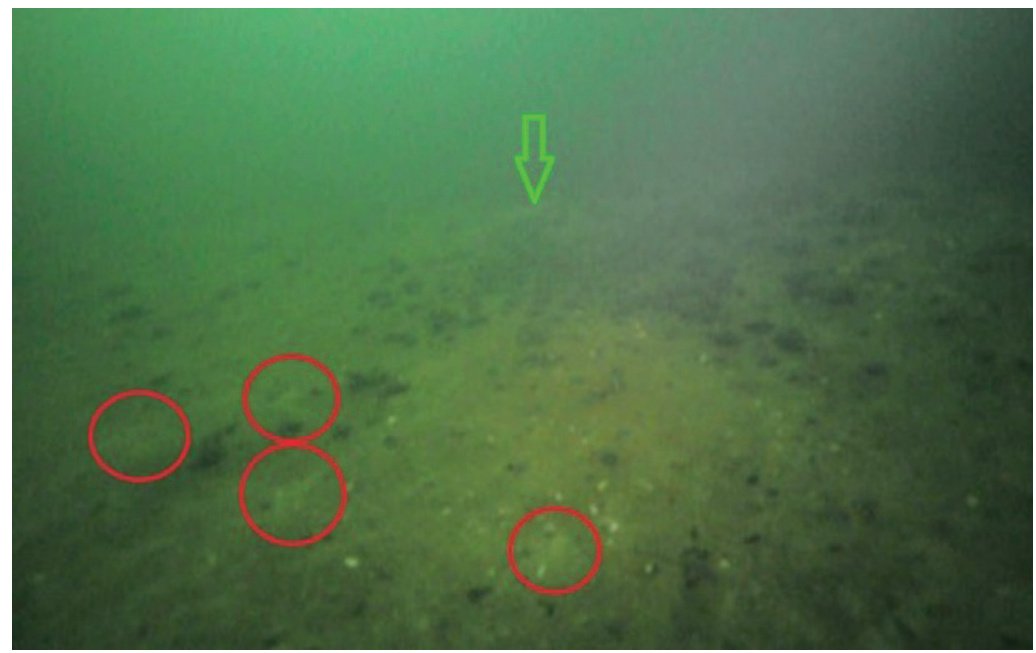

Ryc. 10. Punkty o jaśniejszej barwie piasku kilka metrów przed odnalezionym wypływem nr I (29.01.2012)

Fig. 10. Points of lighter-colored sand a few meters before the rediscovered outflow No. I (29.01.2012)

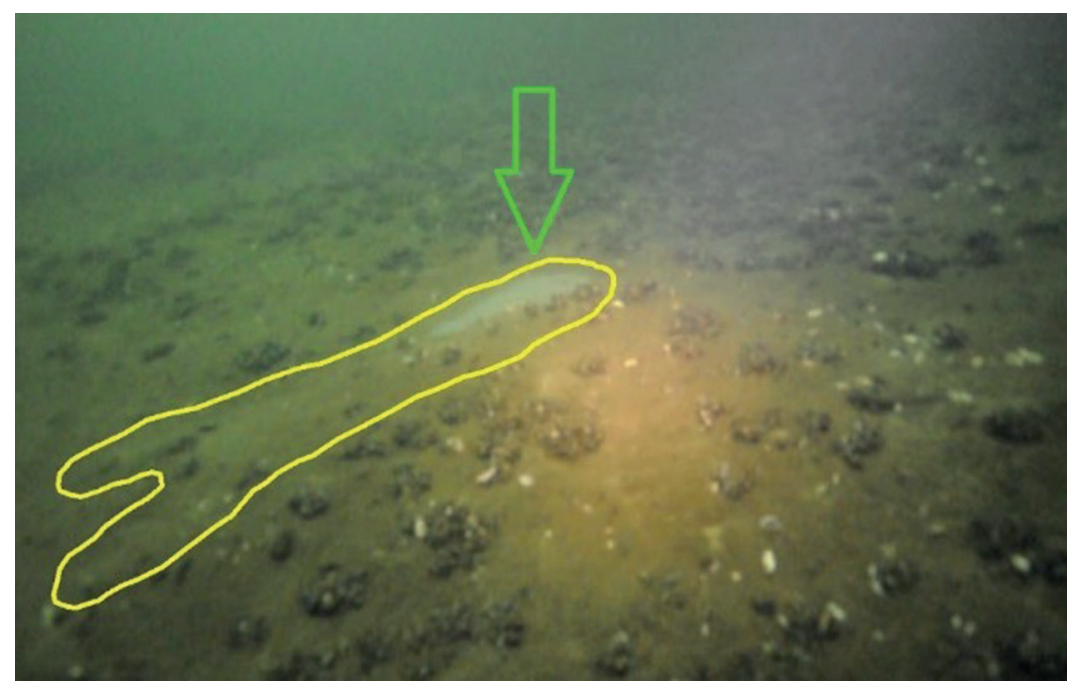

Ryc. 11. Prawdopodobna wielkość stożka wypływu nr I, przy dużym zasilaniu wodą podziemną (29.01.2012)

Fig. 11. Probable outflow No. I cone size, during large underground water flow (29.01.2012) 


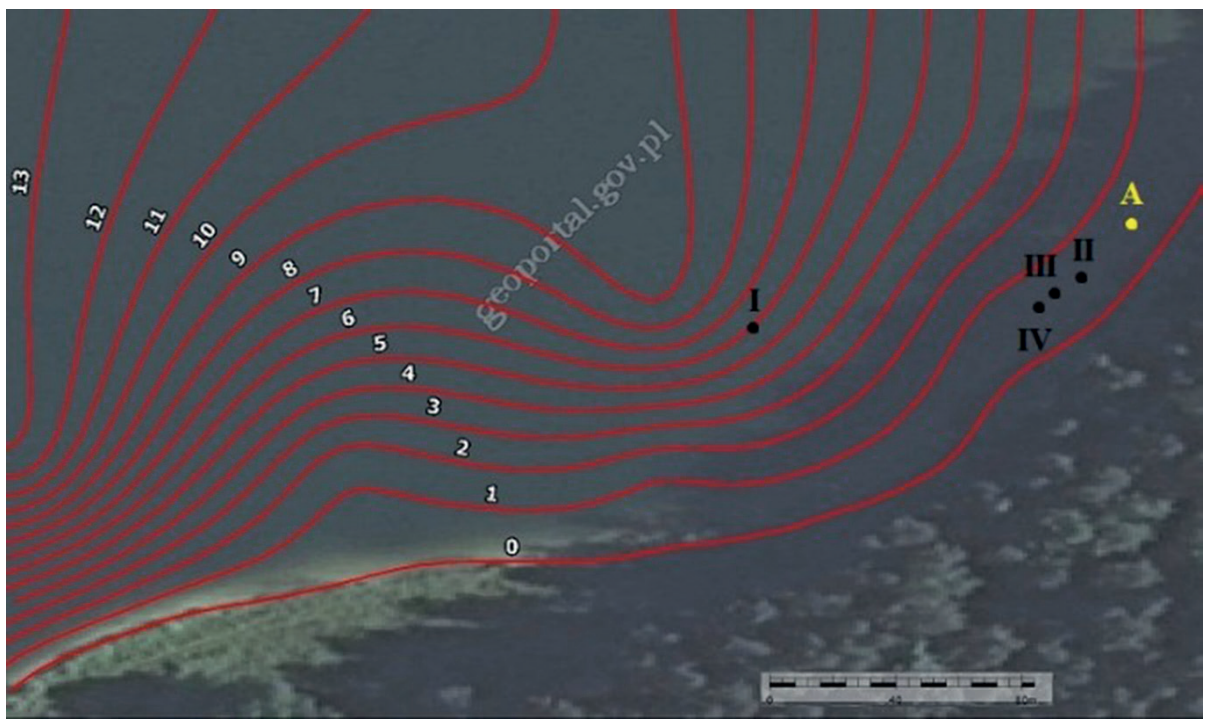

Ryc. 12. Lokalizacja wszystkich odnalezionych źródeł podjeziornych I-IV (kolorem czerwonym oznaczono izobaty) (www.geoportal.gov.pl, 15.01.2016)

Fig. 12. Location of all discovered outflows I-IV (red marked isolates) (www.geoportal.gov.pl, 15.01.2016)

W czasie opływania łódką poligonu badawczego w dniu 18 kwietnia 2012 r. znaleziono kolejne miejsca wypływów wód podziemnych (nr II - 54 $14^{\circ} 46.8^{\prime}$ "

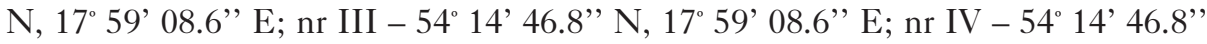
$\mathrm{N}, 17^{\circ} 59^{\prime} 08.6$ ” E). Charakteryzowały się one tak jak poprzednio jasnym („świeżym”) piaskiem. Ze względu na brak sprzętu do badań podwodnych wykonano dokumentację fotograficzną tylko znad wody. Znaleziono trzy wypływy (ryc. 12). Budową przypominały poprzedni znaleziony wypływ, ale w tych przypadkach stożki wypływów były symetrycznie rozproszone wokół punktu, gdzie wydobywała się woda podziemna. Spowodowane to było niewielką głębokością występowania wypływów i płaskim dnem. Wypływy były zlokalizowane na głębokości od 0,5 m do $0,7 \mathrm{~m}$, a stok dna zaczynał się od ok. $1 \mathrm{~m}$ głębokości. W związku z charakterystyką położenia tych wypływów nazywano je źródłami podjeziornymi przybrzeżnymi. Wymiary pierwszego z odnalezionych wypływów przybrzeżnych (ryc. 13) wynosiły w przybliżeniu: $45 \mathrm{~cm}$ szerokości, $45 \mathrm{~cm}$ długości. Kolejne dwa wypływy (ryc. 14) były nieco mniejsze. Drugi miał $12 \mathrm{~cm}$ szerokości oraz $20 \mathrm{~cm}$ długości. Trzeci wypływ miał $20 \mathrm{~cm}$ szerokości $30 \mathrm{~cm}$ długości. Wysokość usypanych przez wypływ stożków wynosiła około $5 \mathrm{~cm}$. 


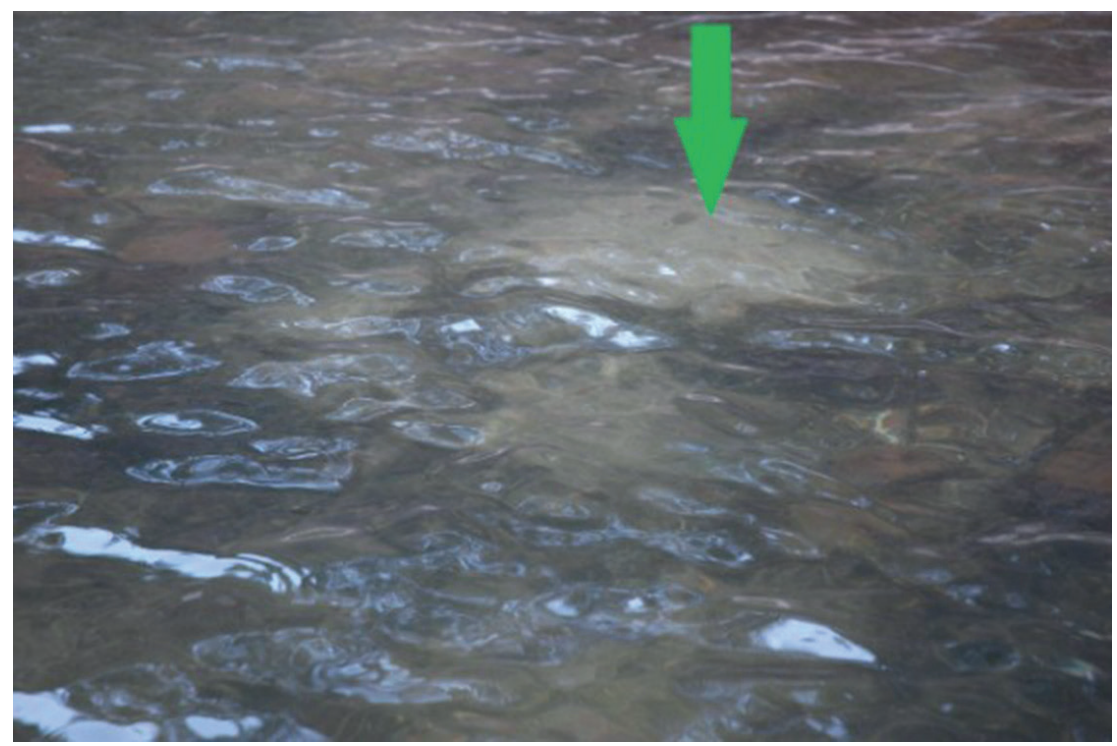

Ryc. 13. Źródło podjeziorne przybrzeżne nr II (18.04.2012)

Fig. 13. Outflow No. II (18.04.2012)

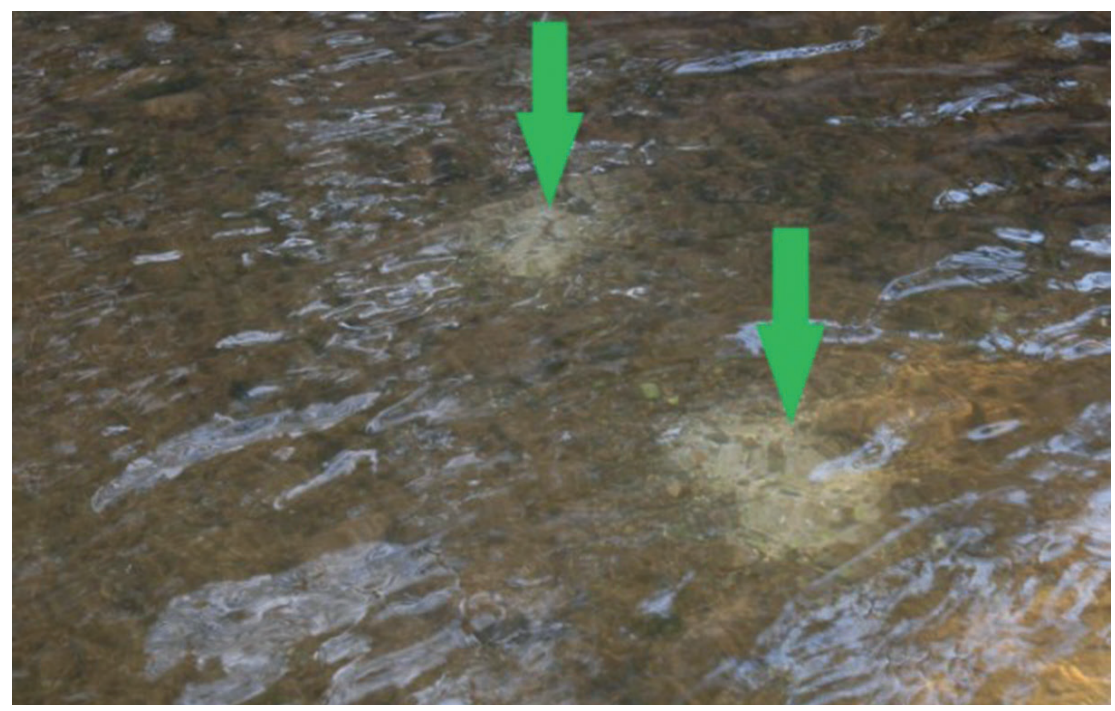

Ryc. 14. Źródła podjeziorne przybrzeżne nr III i IV

Fig. 14. Outflows No. III and IV 
Wszystkie z czterech znalezionych źródeł charakteryzowały się niewielką wydajnością. Źródło $\mathrm{nr}$ I miało - szacunkowo - wydajność ok. $2,5 \mathrm{dm}^{3} \cdot \mathrm{s}^{-1}$. Dla pozostałych trzech źródeł wydajność mieściła się w zakresie od $0,5 \mathrm{dm}^{3} \cdot \mathrm{s}^{-1}$ do $1,0 \mathrm{dm}^{3} \cdot \mathrm{s}^{-1}$ (tab. 1 ). Brak inwentaryzacji źródeł leżących pod wodą w obrębie mis jeziornych nie pozwala na porównanie uzyskanych wyników. Jedynie w pracy Choińskiego (2007) wspomniano, że w przypadku źródła położonego w dnie Jeziora Kobyleckiego jego wydajność wynosi kilka dm $\mathrm{dm}^{3} \cdot \mathrm{s}^{-1}$, a w dnie Jeziora Kielskiego wynosi $2,0 \mathrm{dm}^{3} \cdot \mathrm{s}^{-1}$.

W przypadku temperatury wody jej wyniki w okresie zimowym mieściły się w zakresie od $6,8^{\circ} \mathrm{C}$ do $7,4^{\circ} \mathrm{C}$ (tab. 1), co powodowało ocieplenie strefy przyległej w styczniu (przy powierzchni jeziora temperatura wynosiła od $0,4^{\circ} \mathrm{C}$ do $0,7^{\circ} \mathrm{C}$ ). Latem (lipiec) woda z wypływów powodowała ochłodzenie wód jeziornych. W tym czasie temperatura wody przy wypływach wahała się od $6,5^{\circ} \mathrm{C}$ do $7,0^{\circ} \mathrm{C}$, gdy przy powierzchni wyniosła od $18,2^{\circ} \mathrm{C}$ do $19,3^{\circ} \mathrm{C}$. Zróżnicowanie wyników zaobserwowano również w przypadku wielkości przewodności właściwej. W strefach wypływu jej wartość wahała się od $300 \mu \mathrm{S} \cdot \mathrm{cm}^{-1}$ do $320 \mu \mathrm{S} \cdot \mathrm{cm}^{-1}$ i w miarę oddalania się od źródeł malała do poziomu $250 \mu \mathrm{S} \cdot \mathrm{cm}^{-1}$ do $280 \mu \mathrm{S} \cdot \mathrm{cm}^{-1}$ (tab. 1).

W celu lepszego zobrazowania uzyskanych wyników w tab. 2 zestawiono wszystkie odnalezione źródła podjeziorne na poligonie badawczym w Jeziorze Raduńskim Górnym. Dodatkowo ze względu na zróżnicowanie ich położenia w misie zaproponowano dwa podtypy, tj. źródło podjeziorne stokowe i źródło podjeziorne przybrzeżne.

Tab. 1. Wydajność i właściwości fizyczne wypływów wód podziemnych w dnie misy Jeziora Raduńskiego Górnego

Table 1. Yield and physical properties of groundwater flowing out at the bottom of the basin of Lake Raduńskie Górne

\begin{tabular}{|c|c|c|c|c|c|c|c|c|c|}
\hline \multirow[t]{2}{*}{$\begin{array}{c}\text { Numer } \\
\text { wypływu } \\
\text { Spring } \\
\text { number }\end{array}$} & \multirow[t]{2}{*}{$\begin{array}{c}\text { Wydajność } \\
\text { Discharge } \\
{\left[\mathrm{dm}^{3} \cdot \mathrm{s}^{-1}\right]}\end{array}$} & \multicolumn{2}{|c|}{$\begin{array}{l}\text { Temperatura } \\
\text { w źródle } \\
\text { Spring water } \\
\text { temperature } \\
{\left[{ }^{\circ} \mathrm{C}\right]}\end{array}$} & \multicolumn{2}{|c|}{$\begin{array}{c}\text { Temperatura } \\
\text { przy powierzchni } \\
\text { jeziora } \\
\text { Lake water } \\
\text { temperature } \\
\text { (at the surface) } \\
{\left[{ }^{\circ} \mathrm{C}\right]}\end{array}$} & \multicolumn{2}{|c|}{$\begin{array}{l}\text { Przewodność } \\
\text { w źródle } \\
\text { Conductivity } \\
\text { of spring water } \\
{\left[\mu \mathrm{S} \cdot \mathrm{cm}^{-1}\right]}\end{array}$} & \multicolumn{2}{|c|}{$\begin{array}{c}\text { Przewodność } \\
\text { przy powierzchni jeziora } \\
\text { Conductivity of lake } \\
\text { water } \\
{\left[\mu \mathrm{S} \cdot \mathrm{cm}^{-1}\right]}\end{array}$} \\
\hline & & wiosna & lato & wiosna & lato & wiosna & lato & wiosna & lato \\
\hline I & 2,5 & 7,0 & 7,0 & 0,7 & 18,2 & 300 & 305 & 250 & 260 \\
\hline II & 0,5 & 6,8 & 6,5 & 0,5 & 19,0 & 310 & 315 & 260 & 280 \\
\hline III & 1,0 & 7,4 & 6,6 & 0,5 & 19,3 & 310 & 310 & 270 & 270 \\
\hline IV & 0,6 & 7,2 & 6,8 & 0,4 & 19,1 & 315 & 320 & 260 & 265 \\
\hline
\end{tabular}


Tab. 2. Zestawienie wszystkich znalezionych źródeł podjeziornych w Jeziorze Raduńskim Górnym

Table 2. Summary of all found under-lake springs in Lake Raduńskie Górne

\begin{tabular}{|c|c|c|c|c|}
\hline Lp. & $\begin{array}{l}\text { Współrzędne geograficzne } \\
\text { Coordinates }\end{array}$ & $\begin{array}{l}\text { Głębokość od lustra wody } \\
\text { Depth below lake } \\
\text { water table } \\
{[\mathrm{m}]}\end{array}$ & $\begin{array}{c}\text { Wymiary (dł./szer./wys.) } \\
\text { Dimensions } \\
\text { length/width/height } \\
{[\mathrm{cm}]}\end{array}$ & $\begin{array}{l}\text { Typ wypływu } \\
\text { Spring type }\end{array}$ \\
\hline 1 & $\begin{array}{l}54^{\circ} 14^{\prime} 45.9^{\prime \prime} \mathrm{N} \\
17^{\circ} 59^{\prime} 06.66^{\prime \prime} \mathrm{E}\end{array}$ & 6,0 & $70 / 25 / 7$ & $\begin{array}{c}\text { źródło podjeziorne } \\
\text { stokowe }\end{array}$ \\
\hline II & $\begin{array}{l}54^{\circ} 14^{\prime} 46.8^{\prime \prime} \mathrm{N} \\
17^{\circ} 59^{\prime} 08.6^{\prime \prime} \mathrm{E}\end{array}$ & 0,5 & $45 / 45 / 5$ & $\begin{array}{l}\text { źródło podjeziorne } \\
\text { przybrzeżne }\end{array}$ \\
\hline III & $\begin{array}{l}54^{\circ} 14^{\prime} 46.8^{\prime \prime} \mathrm{N} \\
17^{\circ} 59^{\prime} 08.66^{\prime \prime} \mathrm{E}\end{array}$ & 0,6 & $20 / 12 / 3$ & $\begin{array}{l}\text { źródło podjeziorne } \\
\text { przybrzeżne }\end{array}$ \\
\hline IV & $\begin{array}{l}54^{\circ} 14^{\prime} 46.8^{\prime \prime} \mathrm{N} \\
17^{\circ} 59^{\prime} 08.6 \text { "' } \mathrm{E}\end{array}$ & 0,6 & $30 / 20 / 5$ & $\begin{array}{l}\text { źródło podjeziorne } \\
\text { przybrzeżne }\end{array}$ \\
\hline
\end{tabular}

\section{Dyskusja}

Literatura przedmiotu potwierdza, że wiele jezior o różnej genezie, zlokalizowanych we wszystkich typach krajobrazu, posiada zasilanie drogą podziemną. Zasilanie to ma często ważny udział w bilansie wodnym tych obiektów hydrograficznych. Szczególnie dobrze jest to widoczne w przypadku jezior rynnowych. Są one predysponowane do tego typu zasilania, co należy wiązać ze znaczną ich głębokością i lokalizacją na obszarach polodowcowych o skomplikowanej budowie geologicznej (występuje wiele poziomów wodonośnych) (Piekarek-Jankowska 1973; Jankowska 1979, 1984; Jamorska 2015). W ramach systemów regionalnych dochodzi do złożonych interakcji między wodami podziemnymi i powierzchniowymi, niezależnie od położenia topograficznego jezior. Główną przyczyną złożonych i sezonowo dynamicznych zmian wielkości dopływu wód podziemnych są warunki hydrometeorologiczne (Winter 1999).

Wielkość zasilania jezior drogą podziemną określana jest najczęściej na podstawie bilansu wodnego oraz zmian poziomu wód jeziora oraz przy wykorzystaniu modeli matematycznych (Yihdego, Webb 2012). W przypadku wielu jezior głównym źródłem zasilania jest opad atmosferyczny, a stratą parowanie. Również często jednak znaczące są strumienie wody podziemnej. Przykładowo Jezioro Purrumbete w Australii posiada zasilanie drogą podziemną na poziomie ok. 17\% (Yihdego i in. 2014a). Z kolei straty poprzez odpływ drogą podziemną mogą wynosić nawet 30\% sumy bilansowej, czego przykładem może być jezioro Burrumbeet położone również w Australii (Yihdego, Webb 2015). W przypadku analizowanego jeziora (Raduńskie Górne) wielkość zasilania drogą podziemną szacowana jest przez Okulanisa (1981) na ok. $28 \%$, a straty poprzez odpływ podziemny na ok. $10 \%$. 
Konsekwencją tak znaczącego dopływu wód podziemnych są o wiele mniejsze wahania poziomu wód niż te obserwowane w jeziorach o niewielkim lub znikomym zasilaniu drogą podziemną (Yihdego i in. 2014b). W przypadku Jeziora Raduńskiego Górnego roczne zmiany poziomu wody wynoszą maksymalnie ok. $50 \mathrm{~cm}$ (Okulanis 1981), gdy tymczasem w jeziorach położonych w innych regionach, tj. poza obszarami młodoglacjalnymi, mogą wynieść nawet $150 \mathrm{~cm}$, jak to występuje w przypadku jeziora Resko Przymorskie, które zlokalizowane jest w strefie brzegowej (Dąbrowski 2004).

Co ważne, w przypadku stref o równoważącym się dopływie atmosferycznym i parowaniu lub nadwyżkach opadu nad parowaniem (w takiej strefie położone jest jezioro Raduńskie Górne) widać bardzo dynamiczną relację pomiędzy dopływem atmosferycznym i wodami podziemnymi. Zachodzące interakcje pomiędzy dwoma źródłami zasilania mogą być potencjalnie modyfikowane poprzez oddziaływania antropogeniczne (Smerdon i in. 2005).

Pomimo wiedzy na temat wielkości zasilania jezior drogą podziemną istnieje niewiele pozycji mówiących o liczbie źródeł na dnie mis jeziornych i ich wydajności. Jeśli dochodzi już do inwentaryzacji źródeł, to są to wypływy położone nad brzegiem jezior, najczęściej w strefie krawędziowej i niezakryte wodą lub okresowo zakrywane. O ilości takich źródeł piszą m.in. Smerdon i in. (2005), którzy dla płytkiego jeziora bez nazwy, położonego na terenie Kanady, ustalili, że jest ono zasilane przez 16 stałych źródeł. Liczbę takich źródeł wokół Jeziora Raduńskiego Górnego określa się na 15, a ich wydajność wynosi łącznie $13,81 \cdot \mathrm{s}^{-1}$. Z kolei informacji na temat wypływów zlokalizowanych na dnie mis jeziornych (stale zakrytych wodą) jest zdecydowanie mniej, co wynika z utrudnionego do nich dostępu (często położone są na głębokości kilku do kilkunastu metrów) oraz z potrzeby wykorzystania specjalistycznego sprzętu do ich badań. W przypadku analizowanych wypływów w Jeziorze Raduńskim Górnym ich łączna wydajność wynosi $4,6 \mathrm{dm}^{3} \cdot \mathrm{s}^{-1}$. Dla porównania wydajność wypływów wód podziemnych zlokalizowanych wokół Jeziora Ostrzyckiego wynosi $5,75 \mathrm{dm}^{3} \cdot \mathrm{s}^{-1}$ (Jaworska-Szulc i in. 2015), co jest wartością niewspółmiernie mniejszą od tej dla Jeziora Raduńskiego Górnego, jeśli zsumowalibyśmy wartość notowaną dla źródeł zanurzonych i tych zlokalizowanych wokół jeziora, która wynosi $18,4 \mathrm{dm}^{3} \cdot \mathrm{s}^{-1}$.

Wpływ na zasilanie drogą podziemną mają warunki morfometryczne i geometria jeziora (Townley, Trefry 2010) oraz ukształtowanie powierzchni zlewni bezpośredniej (Zecharias, Brutsaert 1988). Jezioro Raduńskie Górne ze względu na położenie w obniżeniu rynny polodowcowej oraz z uwagi na dużą głębokość spełnia funkcję kontaktową pomiędzy poszczególnymi warstwami wodonośnymi. Również znaczne deniwelacje terenu wokół jeziora sprzyjają zasilaniu drogą podziemną. Może się to odbywać poprzez wypływy wód podziemnych w strefie przyjeziornej w postaci młak, wysięków, źródeł czy przez zasilane bezpośrednio wodami podziemnymi. Hydrogeologicznie istnieją dwie możliwości kontaktu warstw wodonośnych z wodami jeziora, 
tj. gdy pierwszy poziom wód podziemnych kontaktuje się bezpośrednio z wodami jeziora, zasilając je dzięki istniejącym spadkom hydraulicznym, gdy wychodnie warstw wodonośnych na dnie jeziora posiadają wody pod ciśnieniem w przypadku nieznacznego nacięcia warstw wodonośnych w dnie jeziora, w związku z czym spotykamy się z zasilaniem punktowym w postaci źródeł (Choiński 2007). Z kolei według Smitha i Townleya (2002) interakcje między wodami powierzchniowymi i podziemnymi zależą od położenia jeziora w systemie przepływu regionalnego. W konsekwencji zmian zasilania drogą podziemną jezior będzie można obserwować zmiany w ich bilansie wodnym, dynamice zmian zasobów wodnych, wahaniach poziomu wód powierzchniowych, powiązaniach hydraulicznych (Sophocleous 2002) czy zmianach jakości wody (Li, Wang 2007; Dash i in. 2008). Potwierdzeniem, że taka sytuacja występuje w przypadku Jeziora Raduńskiego Górnego, mogą być choćby badania bilansu wodnego przez Okulanisa (1981). Wynika z nich, że po stronie przychodów największy udział miał dopływ podziemny, następnie dopływ powierzchniowy i na końcu opad na powierzchnię jeziora, po stronie zaś rozchodów odpływ powierzchniowy i parowanie (ryc. 15). Z kolei Drwal (1982) wskazuje, że Jezioro Raduńskie Górne stanowi jeden z elementów kaskady jezior raduńsko-ostrzyckich.

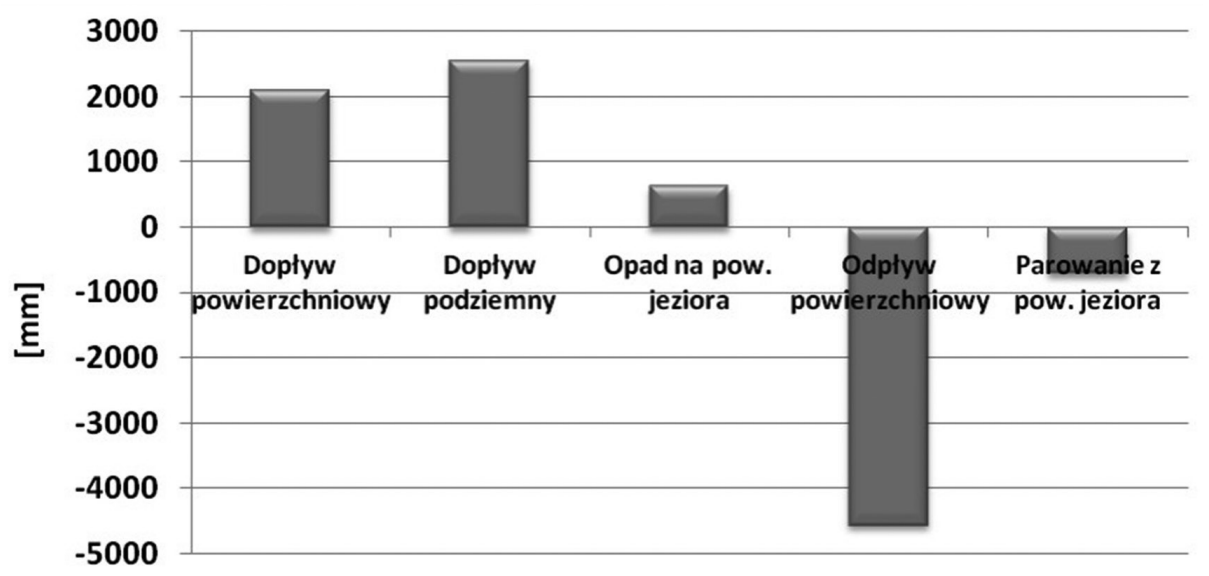

Ryc. 15. Przychody i rozchody bilansu wodnego Jeziora Raduńskiego Górnego wg Okulanisa (1981)

Fig. 15. Revenues and expenditures of the water balance of Lake Raduńskie Górne by Okulanis (1981) 


\section{Podsumowanie}

Na podstawie przeprowadzonych badań w obrębie fragmentu misy jeziora Raduńskiego potwierdzono, że jedną z form zasilania jezior jest zasilanie drogą podziemną. Jest ono obserwowane m.in. w jeziorach rynnowych Pojezierza Kaszubskiego. W trakcie realizacji tematu badań odnaleziono cztery wypływy wód podziemnych. Dla usystematyzowania typologii odkrytych źródeł zaproponowano nowe nazewnictwo, w której wymieniono m.in. źródła podjeziorne, z podtypami: źródło podjeziorne stokowe oraz źródło podjeziorne przybrzeżne.

W przypadku analizowanych wypływów podjeziornych w Jeziorze Raduńskim Górnym ich łączna wydajność wynosi $4,6 \mathrm{dm}^{3} \cdot \mathrm{s}^{-1}$, a wypływów rozmieszczonych wokół misy jeziora $-13,8 \mathrm{dm}^{3} \cdot \mathrm{s}^{-1}$. W przypadku wypływów podjeziornych, gdyby ich wydajność była stała, dałoby to w skali roku dopływ na poziomie około $145000 \mathrm{~m}^{3}$. W przeliczeniu na udział wielkości dopływu podziemnego do Jeziora Raduńskiego Górnego w całkowitym dopływie daje to wartość ok. 0,15\%. Jest on jednak prawdopodobnie zmienny sezonowo, przez co należy przyjąć, że w skali roku da on wartość na poziomie około $75000 \mathrm{~m}^{3}$, co odpowiada udziałowi rzędu $0,08 \%$. Gdybyśmy zsumowali wydajność wypływów podjeziornych i tych zlokalizowanych wokół misy jeziora, otrzymalibyśmy wynik na poziomie $18,4 \mathrm{dm}^{3} \cdot \mathrm{s}^{-1}$, co w skali roku dałoby wartość około $580263 \mathrm{~m}^{3}$. Oczywiście i w tym przypadku jest ona zawyżona, gdyż część z wypływów pojawia się sezonowo, a wydajność jest zmienna w czasie. Można zatem uznać, że dopływ wód tą drogą jest niewspółmiernie mały w stosunku do wielkości całkowitego dopływu podziemnego, który dla Jeziora Raduńskiego Górnego wynosi blisko $97 \mathrm{mln} \mathrm{m}^{3}$ (Okulanis 1981).

Podsumowując, można stwierdzić, że analizowane wypływy wód podziemnych w misie Jeziora Raduńskiego Górnego charakteryzują się znaczną dynamiką. Jednocześnie ze względu na ograniczony obszar badań (poligon badawczy) sugeruje się dalsze kontynuowanie badań w aspekcie ich uszczegółowienia, zwłaszcza w odniesieniu do wypływów przybrzeżnych.

Wydaje się, że zastosowana w pracy metoda - wymagająca sprzętu i umiejętności nurkowania oraz dużych nakładów finansowych, a także potrzeby nabycia różnego rodzaju technik - warta jest zainteresowania. Stosowane do tej pory metody nie pozwalały bowiem na identyfikację części wypływów, które stale znajdują się pod powierzchnią lustra wody, przez co niemożliwa była ocena ich wydajności. Pomimo że technika pomiaru wydajności wymaga poprawy uzyskane wyniki mogą być porównywalne do tych uzyskiwanych w innych metodach pomiarowych. Jednocześnie należy pamiętać, że pomiar ilościowy i jakościowy wypływów wód podziemnych nie może się ograniczać wyłącznie do tych zanurzonych, lecz powinien obejmować także te odkryte i okresowo zanurzone, które rozmieszczone są wokół misy jeziornej. 


\section{Literatura}

Arfib B., de Marsily G., Ganoulis J., 2002, Coastal karst springs in the Mediterranean basin: study of the mechanisms of saline pollution at the Almyros spring (Crete), observations and modeling, Bulletin de la Societe Geologique de France, 173, 245-253.

Błaszkiewicz M., 2007, Geneza i ewolucja mis jeziornych na mtodoglacjalnym obsæarze Polskiwybrane problemy, Studia Limnologica et Telmatologica, 1 (1), 5-16.

Bohacs K.M., Carroll A.R., Neal J.E., Mankiewicz P.J., 2000, Lake-basin type, source potential, and hydrocarbon character: An integrated-sequence-stratigraphic-geochemical framework, AAPG Studies in Geology, 46, 3-34.

Borowiak D., 2005, Struktura hydrograficzna i lokalne warunki obiegu wody, [w:] W. Lange (red.), Jeziora górnej Raduni i jej zlewnia w badaniach z udziatem Stacji Limnologicænej w Borucinie, Wydawnictwo Uniwersytetu Gdańskiego, Gdańsk, 127-142.

Borowiak M., 2006, Influence of hydrographic structure on outflow diversity in Upper Radunia catchment, Limnological Review, 6, 31-38.

Borowiak D., Barańczuk J., 2005, Funkcje hydrologiczne jezior, [w:] W. Lange (red.), Jeziora górnej Raduni i jej zlewnia w badaniach s udziatem Stacji Limnologicะnej w Borucinie, Wydawnictwo Uniwersytetu Gdańskiego, Gdańsk, 215-231.

Choiński A., 2006, Katalog jezior Polski, Wydawnictwo Naukowe UAM, Poznań.

Choiński A., 2007, Limnologia fizyczna, Wydawnictwo Naukowe UAM, Poznań.

Choiński A., Ptak M., 2012, Variation in the ice cover thickness on Lake Samotęskie as a result of underground water supply, Limnological Review, 12 (3), 133-138.

Choiński A., Ilyin L., Marszelewski W., Ptak M., 2008, Lakes Supplied by Springs: Selected Examples, Limnological Review, 8 (4), 145-150.

Dash R.R., Mehrotra I., Kumar P., Grischek T., 2008, Lake bank filtration at Nainital, India: Water-quality evaluation, Hydrogeology Journal, 16, 1089-1099.

Dąbrowski M., 2004, Trends in changes of lake water levels in the Pomerania Lakeland, Limnological Review, 4, 75-80.

Drwal J., 1979, Charakterystyka hydrograficzna, [w:] B. Augustowski (red.), Pojezierze Kaszubskie, Gdańskie Towarzystwo Naukowe, Gdańsk, 121-138.

Drwal J., 1982, Wyks:tatcenie i organizacja sieci hydrograficznej jako podstawa oceny struktury odptywu na terenach mtodoglacjalnych, Wydawnictwo Uniwersytetu Gdańskiego, Gdańsk.

Engstrom D.R., Swain E.B., 1986, The chemistry of lake sediments in time and space, Hydrobiologia, 143 (1), 37-44.

Fetter C.W., 2010, Applied Hydrogeology, Prentice Hall, New Jersey.

Graf R., 2008, Local groundwater-circulation systems in the Warta-Noteć Interfluve (NW Poland), Geologos, 14 (2), 197-210.

Gutry-Korycka M., Bajkiewicz-Grabowska E., 1981, Rola jezior w naturalnym drenaæu podziemnym, Przegląd Geofizyczny, 26 (34), 171-179. 
Harvey F.E., Rudolph D.L., Frape S.K., 2000, Estimating groundwater flux into large lakes: Application in the Hamilton harbor, Western Lake Ontario, Groundwater, 38, 550-565.

Hunt R.J., Haitjema H.M., Krohelski J.T., Feinsten D.T., 2004, Simulating Ground Water-Lake Interactions: Approaches and Insights, Groundwater, 41 (2), 227-237.

Jamorska I., 2015, Warunki występowania wód podziemnych potudniowych Kujaw, Przegląd Geologiczny, 63 (10/1), 756-761.

Jankowska H., 1979, Zwiq̨ki wód podziemnych z jeziorami rynnowymi górnego doræecza Raduni, Wydawnictwo Uniwersytetu Gdańskiego, Gdańsk.

Jankowska H., 1984, Znacznie jezior w ksжtattowaniu się odptywu podziemnego w dorzeczu górnej Raduni, [w:] Rola badań jeziornych w poznawaniu stosunków wodnych pojezierzy, Konferencja Komisji Hydrograficznej Polskiego Towarzystwa Geograficznego Sopot, 25-27 czerwca 1984, Wydawnictwo Uniwersytetu Gdańskiego, Gdańsk, 77-93.

Jaworska-Szulc B., 2015, Ocena sasilania wód podziemnych na Pojezierzu Kaszubskim z zastosowaniem róźnych metod i różnej skali opracowania, Przegląd Geologiczny, 63 (10/1), 762-768.

Jaworska-Szulc B., Pruszkowska-Caceres M., Przewłócka M., 2015, Zmiany wydajności wypływów wód podziemnych mtodoglacjalnego obszaru morenowego na Pojezierzu Kaszubskim, Przegląd Geologiczny, 63 (10/1), 774-779.

Jereczek-Korzeniewska K., 2006, Komentar: do mapy hydrograficznej Polski w skali 1:50000, arkusz N-33-72-B Stężyca, GUGiK, Warszawa.

Jokiel P., 2007, Źródła - wodne perełki na granicy Terry i Hadesu, [w:] P. Jokiel, P. Moniewski, M. Ziułkiewicz (red.), Źródła Polski - wybrane problemy krenologične, Wydawnictwo Uniwersytetu Łódzkiego, Łódź, 7-12.

Krabbenhoft D.P., Anderson M.P., Bowser C.J., 1990, Estimating groundwater exchange with lakes: Calibration of a three-dimensional, solute transport model to a stable isotope plume, Water Resources Research, 26 (10), 2455-2462.

Kaleris V., 2006, Submarine groundwater discharge: Effects of hydrogeology and of near shore surface water bodies, Journal of Hydrology, 325 (1-4), 96-117.

Kidmose J., 2010, Groundwater-surface water interaction: from catchment to interfaces at lakes and streams, PhD dissertation, Faculty of Science, University of Copenhagen, http://www.fiva. dk/doc/thesis/Kidmose_PhD.pdf (23.03.2015).

Lange W. (red.), 2005, Jeziora górnej Raduni i jej slewnia w badaniach z udziatem Stacji Limnologicænej w Borucinie, Wydawnictwo Uniwersytetu Gdańskiego, Gdańsk.

Li Y., Wang Ch., 2007, Theoretical estimation of groundwater discharge and associated nutrient loading to a lake with gentle slope bottom, Journal of Hydrodynamics, 19 (1), 30-35.

Lidzbarski M., 2000, Mapa hydrogeologiczna Polski w skali 1:50 000, arkusz Stężyca, Państwowy Instytut Geologiczny, Gdańsk.

Meyboom P., 1967, Mass-transfer studies to determine the groundwater regime of permanent lakes in hummocky moraine of Western Canada, Journal of Hydrology, 5, 117-142.

Mioduszewski W., Ślesicka A., Querner E., 2004, Warunki «asilania doliny dolnej Biebrzy, Woda - Środowisko - Obszary Wiejskie, 4 (1), 67-78. 
Moniewski P., 2007, Podstawowe pojęcia, typologie i klasyfikacje wspótczesnej krenologii, [w:] P. Jokiel, P. Moniewski, M. Ziułkiewicz (red.), Źródła Polski - wybrane problemy krenologiczne, Wydawnictwo Uniwersytetu Łódzkiego, Łódź, 15-29.

Okulanis E., 1981, Studium limnologiczne Jezior Raduńsko-Ostrzyckich, Gdańskie Towarzystwo Naukowe, Gdańsk.

Piekarek-Jankowska H., 1973, Rola jezior rynnowych w ks»tattowaniu się odpływu wód podziemnych w górnej i srodkowej dolinie Rospudy, Biuletyn Instytutu Geologicznego, 277 (3), 23-33.

Rainey M.P., Tyler A.N., Bryant R.G., Gilvear D.J., McDonald P., 2000, The influence of surface and interstitial moisture on a spectral characteristics of intertidial sediments: Implications for airborne image acquistion and processing, International Journal of Remote Sensing, 21 (16), 3025-3038.

Schuster P.F., Reddy M.M., LaBaugh J.W., Parkhurst R.S., Rosenberry D.O., Winter T.C., Antweiler R.C., Dean W.E., 2003, Characterization of lake water and ground water movement in the littoral zone of Williams Lake, a closed-basin lake in north central Minnesota, Hydrological Processes, 17 (4), 823-838.

Shanks III W.C., Callender E., 1992, Thermal springs in Lake Baikal, Geology, 20, 495-497.

Shaw R.D., Prepas E.E., 1990, Groundwater - lake interactions: Nearshore seepage patterns and the contribution of ground water to lakes in central Alberta, Journal of Hydrology, 119 (1-4), 121-136.

Smerdon B.D., Devito K.J., Mendoza C.A., 2005, Interaction of groundwater and shallow lakes on outwash sediments in the sub-humid Boreal Plains of Canada, Journal of Hydrology, 314 (1-4), 246-262.

Smith A.J., Townley L.R., 2002, Influence of regional setting on the interaction between shallow lakes and aquifers, Water Resources Research, 38 (9), 10-13.

Sophocleous M., 2002, Interactions between groundwater and surface water: The state of the science, Hydrogeology Journal, 10 (1), 52-67.

Szumińska D., 2014, Runoff in the Wda drainage basin against the background of water management in the second half of the 20th century, Wydawnictwo Uniwersytetu Kazimierza Wielkiego, Bydgoszcz.

Taniguchi M. Burnett W.C. Cable J.E., Turner J.V., 2002, Investigation of submarine groundwater discharge, Hydrological Processes, 16 (11), 2115-2129.

Tarka R., 1995, Optymalizacja pomiarów hydrologicænych w wy»naczaniu odpływu podziemnego metodq źródet reprezentatywnych, Gospodarka Wodna, 3, 6-13.

Tomalski P., Tomaszewski E., 2007, Alimentacja wód śródlanych i ich rola w strukturze odptywu matej zlewni nizinnej, [w:] P. Jokiel, P. Moniewski, M. Ziułkiewicz (red.), Źródła Polski. Wybrane problemy krenologiczne, Wydział Nauk Geograficznych Uniwersytetu Łódzkiego, Regina Poloniae, Łódź-Częstochowa, 142-152.

Tomaszewski J., 1989, Badanie naturalnych wyphywów wód podziemnych, [w:] M. Gutry-Korycka, H. Werner-Więckowska (red.), Præewodnik do hydrografičnych badan terenowych, PWN, Warszawa, 104-116. 
Townley L.R., Trefry M.G., 2010, Surface water-groundwater interaction near shallow circular lakes: Flow geometry in three dimensions, Water Resources Research, 36 (4), 935-948.

Winter T.C., 1999, Relation of streams, lakes, and wetlands to groundwater flow systems, Hydrogeology Journal, 7 (1), 28-45.

Wüest A., Lorke A., 2003, Small-scale hydrodynamics in lakes, Annual Review of Fluid Mechanics, 35 (1), 373-412.

Yihdego Y., Becht R., 2013, Simulation of lake-aquifer interaction at Lake Naivasha, Kenya using a three-dimensional flow model with the high conductivity technique and a DEM with bathymetry, Journal of Hydrology, 503, 111-122.

Yihdego Y., Webb J., 2012, Modelling of seasonal and long-term trends in lake salinity in South-Western Victoria, Australia, Journal of Environmental Management, 112, 149-159.

Yihdego Y., Webb J.A., 2015, Use of a conceptual hydrogeological model and a time variant water budget analysis to determine controls on salinity in Lake Burrumbeet in southeast Australia, Environmental Earth Sciences Journal, 73 (4), 1587-1600.

Yihdego Y, Webb J.A., Leahy P., 2014a, Modelling of lake level under climate change conditions: Lake Purrumbete in southeastern Australia, Environmental Earth Sciences Journal, 73, 3855-3872.

Yihdego Y., Webb J., Leahy P., 2014b, Modelling water and salt balances in a deep, groundwater-through flow lake - Lake Purrumbete, southeastern Australia, Hydrological Sciences Journal, 61, 186-199.

Younger P.L., 2009, Groundwater in the Environment, John Wiley \& Sons, New Jersey.

Zecharias Y.B. Brutsaert W., 1988, The influence of basin morphology on groundwater outflow, Water Resources Research, 24 (10), 1645-1650.

\author{
Roman Cieśliński \\ Uniwersytet Gdanski \\ Katedra Hydrologii \\ ul. Bä̇yńskiego 4, 80-952 Gdańsk \\ georc@univ.gda.pl \\ Jacek Piekar: \\ Uniwersytet Gdański \\ Katedra Hydrologii \\ ul. Bażyńskiego 4, 80-952 Gdańsk \\ schabun@gazeta.pl
}


